Check for updates

Cite this: RSC Adv., 2018, 8, 27027

\title{
Hexavalent chromium ion and methyl orange dye uptake via a silk protein sericin-chitosan conjugate $\uparrow$
}

\author{
Swatantra Pratap Singh, (D) Karthik Rathinam, (D) $\$$ Roni Kasher (D)* \\ and Christopher J. Arnusch (D)*
}

\begin{abstract}
Sericin, a protein waste product of the silk industry, was crosslinked with chitosan, and a chitosan-sericin conjugate (CS) was prepared, characterized and used to remove hexavalent chromium (Cr(vI)) ions and methyl orange (MO) dye from aqueous solutions. The CS was shown to effectively remove $\mathrm{Cr}(\mathrm{VI})$ ions and $\mathrm{MO}$ dye at maximum adsorption capacities (Langmuir) of $139 \mathrm{mg} \mathrm{g}^{-1}$ for $\mathrm{Cr}\left(\mathrm{vl}\right.$ ) ions and $385 \mathrm{mg} \mathrm{g}^{-1}$ for $\mathrm{MO}$ dye. Moreover, the adsorption of both $\mathrm{Cr}(\mathrm{VI})$ ions and $\mathrm{MO}$ dye was highly $\mathrm{pH}$ dependent and varied under different experimental conditions. $\mathrm{Cr}(\mathrm{VI})$ ion and $\mathrm{MO}$ dye uptake by the CS was confirmed by attenuated total reflectance Fourier transform infrared spectroscopy, X-ray photoelectron spectroscopy (XPS) and energy dispersive spectrometry analysis. Additionally, XPS analysis of the Cr(vı)loaded CS revealed that $\mathrm{Cr}(\mathrm{VI})$ was reduced to the less toxic $\mathrm{Cr}(\mathrm{II})$. The CS was shown not only to be highly amenable to regeneration, but also to be able to effectively remove $\mathrm{MO}$ dye and $\mathrm{Cr}(\mathrm{vI})$ ions from a binary mixture.
\end{abstract}

Received 7th May 2018

Accepted 24th July 2018

DOI: $10.1039 / \mathrm{c} 8 \mathrm{ra03907k}$

rsc.li/rsc-advances composites - e.g., graphene oxide-chitosan, ${ }^{22}$ zirconium crosslinked chitosan, ${ }^{23}$ chitosan/silica gel, ${ }^{24}$ chitosan/bentonite, ${ }^{25,26}$ magnetic chitosan, ${ }^{27}$ and magnetic graphene oxide-chitosan, ${ }^{28}$ among others - were also shown to be effective in the adsorption of dyes and heavy metals from water. Such chitosan composites are advantageous and necessary if an insoluble adsorbent is required, since the solubility of un-crosslinked chitosan in acidic media is high. ${ }^{29}$

Sericin, a water soluble protein derived from the silkworm Bombyx mori that constitutes $25-30 \%$ of silk protein, ${ }^{30,31}$ is a waste product of silk processing that has been shown to be important in a variety of applications, e.g., medical biomaterials and biomedicine, ${ }^{32,33}$ Briefly, sericin comprises 17 different types of amino acids, and it has a molecular mass $>200 \mathrm{kD} .^{31}$ Its main amino acids are serine, glycine and aspartic acid ( $\sim 75 \%)$, and the remainder of its composition ( $\sim 25 \%)$ comprises another 14 amino acids. In addition, sericin has both hydrophilic and hydrophobic as well as positively and negatively charged residues, which may confer on it exceptional binding capacities for heavy metals and other pollutants via noncovalent interactions. Similarly, Karpus et al. recently showed the specific binding of $\mathrm{Cr}(\mathrm{VI})$ ions by the molybdate-binding protein $\operatorname{ModA}^{34}$ and Kwak et al. recently showed $\operatorname{Cr}(\mathrm{vI})$ removal with sericin beads. ${ }^{35}$ Hence, the incorporation of proteins into composites with adsorbent materials might be a viable strategy to improve the adsorption capacities of the adsorbent materials, as well as create an insoluble adsorbent from two materials that are soluble in various aqueous media. Moreover, the conversion of waste product into a valuable,
Department of Desalination and Water Treatment, Zuckerberg Institute for Water Research, The Blaustein Institutes for Desert Research, Ben-Gurion University of the Negev, Sede Boqer Campus, 84990, Israel.E-mail: kasher@bgu.ac.il; arnusch@bgu.ac.il $\dagger$ Electronic supplementary information (ESI) available. See DOI: 10.1039/c8ra03907k

\$ Authors with equal contribution. 
environmentally friendly material has both industrial and societal benefits.

In the present study, we synthesized a chitosan and sericin conjugate via crosslinking with glutaraldehyde. The resulting chitosan-sericin conjugate (CS) was thoroughly characterized using spectroscopic techniques. Its adsorption performance was tested by batch experiments using hexavalent chromium $(\mathrm{Cr}(\mathrm{vI}))$ ions and methyl orange (MO) dye as models for inorganic and organic pollutants, respectively. Widely used in the leather tanning, electroplating, and metal polishing industries, the $\mathrm{Cr}(\mathrm{VI})$ ion is thought to be 1000 times more toxic than $\mathrm{Cr}(\mathrm{III})$, and it is known to cause allergies, skin ulcerations, and damage to the livers, kidneys and blood cells. Due to its high toxicity and bioaccumulation, $\mathrm{Cr}(\mathrm{vI})$ must be removed from effluents before wastewater is discharged to the environment. To thoroughly describe the adsorption process and determine its rate, the parameters associated with the isotherm models, thermodynamic studies, and kinetic models were investigated in detail. We investigated the adsorption of $\mathrm{Cr}(\mathrm{vI})$ ions and MO dye by the CS under different experimental conditions. In brief, our findings showed significant pollutant removal and a high potential for regeneration and reuse of CS. Moreover, the influence of solution $\mathrm{pH}$ on the $\mathrm{Cr}(\mathrm{VI})$ ion and $\mathrm{MO}$ dye removal efficiencies by CS was studied. In all the $\mathrm{pH}$ ranges examined, CS exhibited higher selectivity for the MO dye than for the $\mathrm{Cr}(\mathrm{vI})$ ions.

\section{Materials and methods}

\subsection{Materials}

Sericin from the silkworm Bombyx mori, medium molecular weight chitosan, glutaraldehyde, and 1,5-diphenylcarbazide were purchased from Sigma Aldrich, Israel. Methyl orange and potassium dichromate $\left(\mathrm{K}_{2} \mathrm{Cr}_{2} \mathrm{O}_{7}\right)$, sodium nitrate $\left(\mathrm{NaNO}_{3}\right)$, sodium sulfate $\left(\mathrm{Na}_{2} \mathrm{SO}_{4}\right)$, sodium bicarbonate $\left(\mathrm{NaHCO}_{3}\right)$, sodium chloride $(\mathrm{NaCl})$, sodium hydroxide $(\mathrm{NaOH})$ and hydrochloric acid $(\mathrm{HCl})$ were procured from Frutarom (Haifa, Israel). Deionized water (DI) was used to prepare all the solutions.

\subsection{Preparation of CS}

Solutions of chitosan $(1 \%, \mathrm{w} / \mathrm{v})$ and sericin $(0.5 \%, \mathrm{w} / \mathrm{v})$ were prepared separately by dissolving the former in acetic acid solution $(2 \%, v / v)$ and the latter in DI water. Thereafter, the chitosan and sericin solutions were mixed together and stirred for $1.5 \mathrm{~h}$ until a homogeneous solution was obtained. Glutaraldehyde $(2.5 \%)$ was then added to the solution, the solution was mixed, and the reaction mixture was kept at $0-4{ }^{\circ} \mathrm{C}$ for $24 \mathrm{~h}$ to ensure maximum crosslinking. After $24 \mathrm{~h}$, the resultant CS conjugate was filtered and thoroughly washed with DI several times to remove unreacted sericin and glutaraldehyde. After it was dried in a hot air oven at $40^{\circ} \mathrm{C}$ for $72 \mathrm{~h}$, it was ready for use in further experiments.

\subsection{CS characterization}

The CS was characterized by using attenuated total reflectanceFourier transform infra-red spectroscopy (ATR-FTIR), scanning electron microscopy (SEM), energy dispersive X-ray spectroscopy (EDX), X-ray photoelectron spectroscopy (XPS), Brunauer-Emmett-Teller (BET) surface area and thermogravimetric analysis (TGA).

The salt addition method was adopted to determine the zero point charge $\left(\mathrm{pH}_{\mathrm{zpc}}\right)$ of the $\mathrm{CS}$ in an $\mathrm{NaCl}$ solution $(0.01 \mathrm{M}){ }^{36,37}$ In brief, the initial $\mathrm{pH}$ of the $\mathrm{NaCl}$ solution was adjusted from $\mathrm{pH} 2$ to $\mathrm{pH} 10$ using $0.1 \mathrm{M} \mathrm{HCl} / \mathrm{NaOH}$. Thereafter, the CS $(0.15 \mathrm{~g})$ was added to $50 \mathrm{~mL}$ of $\mathrm{NaCl}$ solution, the mixture was equilibrated for $24 \mathrm{~h}$ under static conditions and its final $\mathrm{pH}$ was measured. The difference between the initial and final $\mathrm{pH}$, i.e., $\Delta \mathrm{pH}$, was noted and plotted against the initial $\mathrm{pH}$. The $\mathrm{pH}$ at which $\Delta \mathrm{pH}=0$ is known as the $\mathrm{pH}_{\mathrm{ZPC}}$ of the CS.

\subsection{Removal of $\mathrm{Cr}(\mathrm{vr})$ ions and MO dye using CS}

$\mathrm{Cr}(\mathrm{VI})$ ions and MO dye were removed by using the batch method, and all of the adsorption experiments were done in $20 \mathrm{~mL}$ closed glass vials. In a typical adsorption experiment, a known amount of CS was added to $10 \mathrm{~mL}$ of adsorbate that comprised either MO dye at concentrations of $50-150 \mathrm{mg} \mathrm{L}^{-1}$ or $\mathrm{Cr}(\mathrm{vI})$ ions at concentrations of $50-100 \mathrm{mg} \mathrm{L}^{-1}$ solution. The resultant mixture was then agitated at $150 \mathrm{rpm}$ for $60 \mathrm{~min}$, after which the solution was filtered and analyzed for residual MO dye using a UV-Vis spectrophotometer at $464 \mathrm{~nm}$ and for residual $\mathrm{Cr}(\mathrm{vI})$ ions using the 1,5-diphenylcarbazide method. ${ }^{20,38}$ With the exception of the $\mathrm{pH}$ experiment, all the adsorption experiments were carried out at $\mathrm{pH} 7$ by adjusting the initial solution $\mathrm{pH}$ of the adsorbate by adding either $0.1 \mathrm{M} \mathrm{HCl}$ or $\mathrm{NaOH}$ to the solution. The adsorption capacities and removal efficiencies were calculated by using mass balance equations [eqn (1) and (2)]:

$$
\begin{gathered}
q_{\mathrm{e}}=\left(C_{0}-C_{\mathrm{e}}\right) \times \frac{V}{M} \\
\operatorname{Removal}(\%)=\left(C_{0}-C_{\mathrm{e}}\right) / C_{0} \times 100
\end{gathered}
$$

where $q_{\mathrm{e}}$ is the equilibrium adsorption capacity $\left(\mathrm{mg} \mathrm{g}^{-1}\right), \mathrm{C}_{0}$ and $C_{\mathrm{e}}$ are the initial and equilibrium adsorbate concentrations, respectively $\left(\mathrm{mg} \mathrm{L}^{-1}\right), V$ is the volume of the adsorbate solution (L), and $M$ is the mass of the CS (g). Effects of pH: the effects of solution $\mathrm{pH}(3-9)$ on the adsorption capacities were investigated. In short, $5 \mathrm{mg}$ of the $\mathrm{CS}$ was added to $10 \mathrm{~mL}$ of solution (different $\mathrm{pH}$ ) of either $50 \mathrm{mg} \mathrm{L}^{-1}$ of MO dye or $50 \mathrm{mg} \mathrm{L}^{-1}$ of $\mathrm{Cr}(\mathrm{vI})$ ions and agitated at $150 \mathrm{rpm}$ for $60 \mathrm{~min}$. Effects of CS dosage: removal efficiencies of $\mathrm{Cr}(\mathrm{vI})$ ions and MO dye by the CS were investigated by using different amounts of the CS ( 1 to $7 \mathrm{mg})$ in a $10 \mathrm{~mL} \mathrm{MO} \mathrm{dye/Cr(vI)} \mathrm{ion} \mathrm{solution.} \mathrm{All}$ experiments were done at $\mathrm{pH} 7$ and under agitation for $60 \mathrm{~min}$ with $50 \mathrm{mg} \mathrm{L}^{-1}$ concentrations of both $\mathrm{MO}$ dye and $\mathrm{Cr}(\mathrm{vI})$ ions. Effects of ionic strength: The removal of MO dye $\left(50 \mathrm{mg} \mathrm{L}^{-1}\right)$ and $\mathrm{Cr}(\mathrm{vI})$ ions $\left(50 \mathrm{mg} \mathrm{L}^{-1}\right)$ by the $\mathrm{CS}$ was studied under different ionic strengths from 0 to $0.7 \mathrm{M}$ using $\mathrm{NaCl}$. The experiments were done at $\mathrm{pH} 7$ with $5.0 \mathrm{mg}$ of $\mathrm{CS}$ in $10 \mathrm{~mL}$ of solution with $60 \mathrm{~min}$ contact times. Effects of co-ions: the effects of co-ions, such as nitrate $\left(\mathrm{NO}_{3}{ }^{-}\right)$, sulfate $\left(\mathrm{SO}_{4}{ }^{2-}\right)$, bicarbonate $\left(\mathrm{HCO}_{3}{ }^{-}\right)$and chloride $\left(\mathrm{Cl}^{-}\right)$ions, on the removal of MO dye and $\mathrm{Cr}(\mathrm{vI})$ ions $\left(50 \mathrm{mg} \mathrm{L}^{-1}\right)$ by the CS were tested. 
$\mathrm{NaNO}_{3}, \mathrm{Na}_{2} \mathrm{SO}_{4}, \mathrm{NaHCO}_{3}$ and $\mathrm{NaCl}$ salts were used to prepare the respective stock solution of anions $\left(1000 \mathrm{mg} \mathrm{L}^{-1}\right)$. The adsorption experiments were carried out in the presence of these anions $\left(50 \mathrm{mg} \mathrm{L}^{-1}\right)$ by keeping other parameters constant as mentioned in the ionic strength experiments. Co-adsorption of MO dye and $\mathrm{Cr}(\mathrm{vI})$ ions by the CS: the co-adsorption of MO dye and $\mathrm{Cr}(\mathrm{vI})$ ions by the CS was investigated with respect to different initial $\mathrm{pH}$ conditions. A single solution containing $50 \mathrm{mg} \mathrm{L}^{-1}$ of both MO dye and $\mathrm{Cr}(\mathrm{vI})$ ions was prepared and the initial solution $\mathrm{pH}$ was adjusted from $\mathrm{pH} 3$ to $\mathrm{pH} 9$ by using $0.1 \mathrm{M} \mathrm{HCl} / \mathrm{NaOH}$. In this experiment, $5 \mathrm{mg}$ of the $\mathrm{CS}$ was added to $10 \mathrm{~mL}$ of the mixed $\mathrm{Cr}(\mathrm{vI})$ ions and MO dye solution, agitated at $150 \mathrm{rpm}$ for $60 \mathrm{~min}$ and the samples were taken for analysis. Adsorption kinetics: adsorption kinetics experiments were done at $298 \mathrm{~K}$ with different initial concentrations of MO dye (50, 100 and $150 \mathrm{mg} \mathrm{L}^{-1}$ ) and $\mathrm{Cr}(\mathrm{vI})$ ions (50, 75 and $\left.100 \mathrm{mg} \mathrm{L}^{-1}\right)$. Pseudo-first-order, pseudo-second-order and intraparticle kinetic models were used to fit the kinetics data. The linear forms of these kinetics models are given in the ESI in eqn (S1S3). $\dagger$ Adsorption isotherms and thermodynamic studies: these studies were performed under optimized conditions at several temperatures (298, 308 and $318 \mathrm{~K}$ ) and with varied initial concentrations of MO dye $\left(50,100\right.$ and $\left.150 \mathrm{mg} \mathrm{L}^{-1}\right)$ and $\mathrm{Cr}(\mathrm{vI})$ ions $\left(50,75\right.$ and $\left.100 \mathrm{mg} \mathrm{L}^{-1}\right)$. Langmuir, Freundlich and D-R isotherm models were adapted to fit the isotherm data to explain the adsorption process. The linear forms of these isotherm models are provided in the ESI [eqn (S4-S6)].†

\subsection{Desorption and reuse experiments}

Prior to the desorption and reuse experiments, the adsorption of MO dye (50 $\left.\mathrm{mg} \mathrm{L}^{-1}\right)$ and $\mathrm{Cr}(\mathrm{vI})$ ions $\left(50 \mathrm{mg} \mathrm{L}^{-1}\right)$ on CS was performed under optimized conditions. For the adsorption experiments, $0.05 \mathrm{~g}$ of $\mathrm{CS}$ was added to $100 \mathrm{~mL}$ of a $\mathrm{MO} / \mathrm{Cr}(\mathrm{vI})$ ion solution and then agitated for $60 \mathrm{~min}$. After the adsorption, the exhausted CS was washed with water to remove unadsorbed $\mathrm{MO} / \mathrm{Cr}(\mathrm{vI})$ ions and then dried under vacuum. The desorption of adsorbed MO and $\mathrm{Cr}(\mathrm{vI})$ ions was done with $0.5 \mathrm{M} \mathrm{NaOH}$ for $60 \mathrm{~min}$. After desorption, the CS was washed with water several times, vacuum dried and used for the next adsorption cycles.

\section{Results and discussion}

\subsection{CS characterization}

Chitosan and sericin were crosslinked using glutaraldehyde, a low-cost and well-known crosslinker that reacts quickly and indiscriminately with amino groups, ${ }^{39-41}$ especially with amines at neutral $\mathrm{pH}$, to generate thermally and chemically stable crosslinks. The resulting insoluble conjugate was washed thoroughly in order to remove any unreacted reagents. ATRFTIR: ATR-FTIR characterization of the chitosan (Fig. 1A) showed a broad peak around $3000-3600 \mathrm{~cm}^{-1}$ that was attributed to the stretching vibrations of the $-\mathrm{OH}$ and $-\mathrm{NH}$ groups, while $-\mathrm{CO}-\mathrm{NH},-\mathrm{NH}_{2}$ and $-\mathrm{C}-\mathrm{N}$ groups were located at 1645 , 1580 and $1315 \mathrm{~cm}^{-1}$, respectively. Also, the peaks that appeared at 1030 and $2920 \mathrm{~cm}^{-1}$ were attributed to the stretching
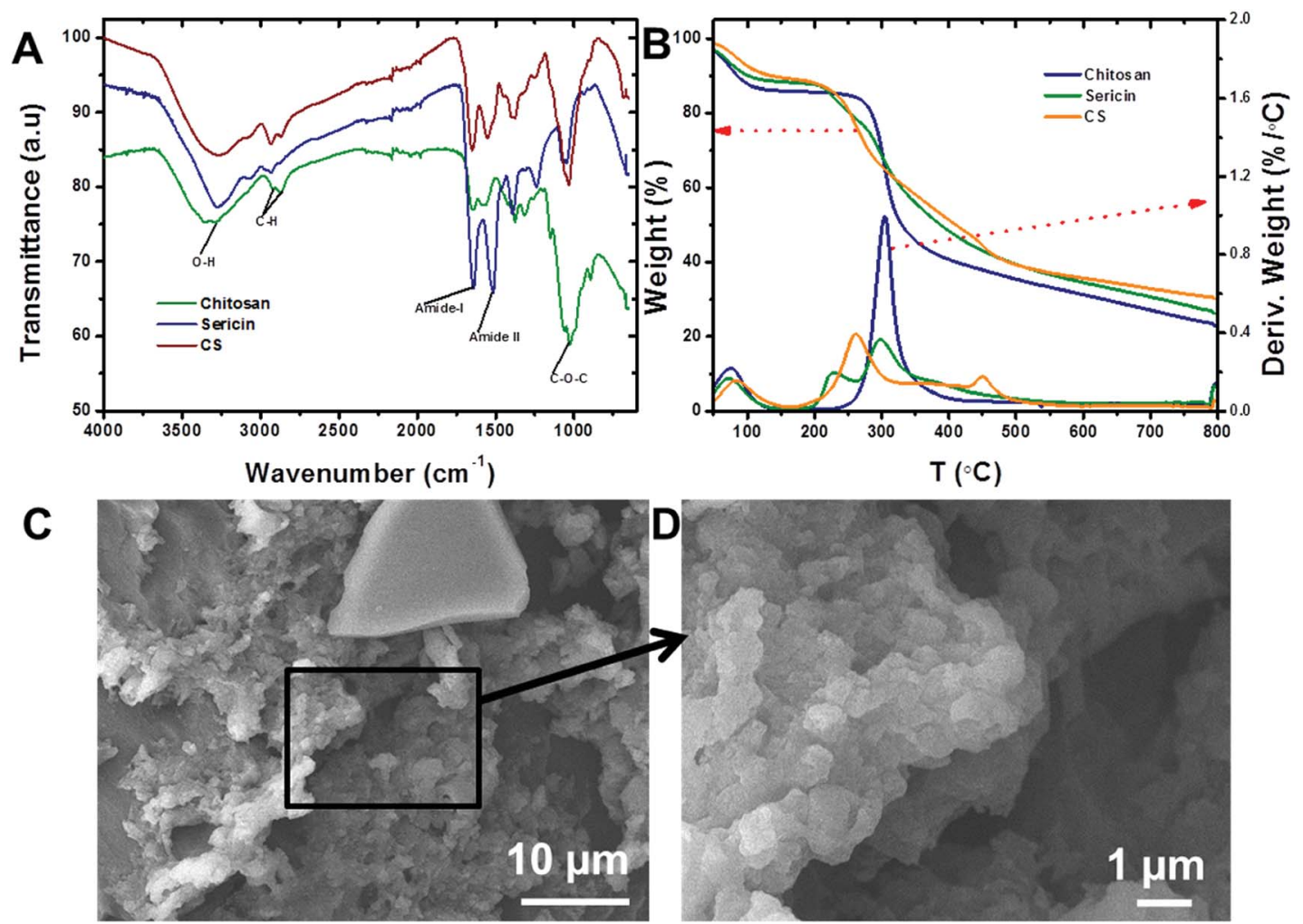

Fig. 1 (A) ATR-FTIR spectra of chitosan, sericin and CS. (B) TGA curves for chitosan, sericin and CS. (C) Low resolution and (D) higher resolution SEM images of the CS. 
vibrational frequencies of the $-\mathrm{C}-\mathrm{O}$ and $-\mathrm{CH}_{2}$ groups, respectively. ${ }^{42}$ Similarly, the peaks observed for sericin at 3280, 1640 and $1515 \mathrm{~cm}^{-1}$ corresponded to the stretching vibrational frequencies of the $-\mathrm{NH}$, amide $\mathrm{I}(-\mathrm{CO}-\mathrm{NH})$ and amide II groups, respectively. ${ }^{42}$ In addition, peaks attributed to $-\mathrm{OH},-\mathrm{NH}$ and -C-O also appeared at 1398, 1239 and $1071 \mathrm{~cm}^{-1}$, respectively. Notably, after the incorporation of sericin into chitosan, the peak corresponding to $-\mathrm{NH}_{2}$ in chitosan at $1580 \mathrm{~cm}^{-1}$ shifted to $1552 \mathrm{~cm}^{-1}$ and new peaks corresponding to $-\mathrm{OH}$ and $-\mathrm{NH}$ (sericin) appeared at 1241 and $1398 \mathrm{~cm}^{-1}$. These observations suggested that the sericin and chitosan successfully combined to form a CS conjugate. TGA: thermogravimetric analysis (TGA) and derivative TGA curves of sericin, chitosan, and CS show that from 30 to $800{ }^{\circ} \mathrm{C}$, chitosan exhibited three stages of degradation while both sericin and CS exhibited four (Fig. 1B). In chitosan and CS, the first stage degradation was mainly due to water evaporation while the second, third and fourth stage degradations corresponded to dehydration, depolymerization, and decomposition of the polysaccharides. ${ }^{43}$ Furthermore, the $74 \%$ loss in mass of sericin was accounted for vis-à-vis the four stages of degradation during the heating process. As for CS and chitosan, in the case of sericin, the first stage degradation, which occurred over a temperature range of 30 to $160{ }^{\circ} \mathrm{C}$, corresponded to water loss $(12 \%)$. The remaining degradation stages may have been due to the decomposition of protein structures. At $70 \%$, the loss in mass of the CS was the lowest of the three substances tested. After CS were sericin (74\%) and chitosan (78\%). This analysis revealed that the incorporation of sericin into the chitosan improved the thermal stability of the latter. BET surface area and SEM: BET surface area, pore diameter and pore volume of the CS conjugate were measured to be $49.06 \mathrm{~m}^{2} \mathrm{~g}^{-1}, 1.489 \mathrm{~nm}$, and $0.068 \mathrm{cc} \mathrm{g}^{-1}$, respectively. The porous morphology of the CS evident in the SEM images (Fig. 1C and D) could account for its high surface area.

\subsection{Removal of $\mathrm{Cr}(\mathrm{vI})$ ions and MO dye using CS}

Effects of contact time and initial concentration. The influence of contact time and initial concentrations of $\mathrm{Cr}(\mathrm{VI})$ ions and MO dyes on the adsorption capacities of CS were investigated and found that CS adsorption capacities were increased with the increase in initial concentration and contact time. This is probably due to the availability of higher adsorption sites the initial rate of adsorption was very fast and equilibrium was reached at $60 \mathrm{~min}$ for both $\mathrm{Cr}(\mathrm{vI})$ ions and $\mathrm{MO}$ dye (Fig. 2A and B).

Kinetics. The rates of the adsorption processes were depicted using pseudo-first-order, pseudo-second-order and intraparticle
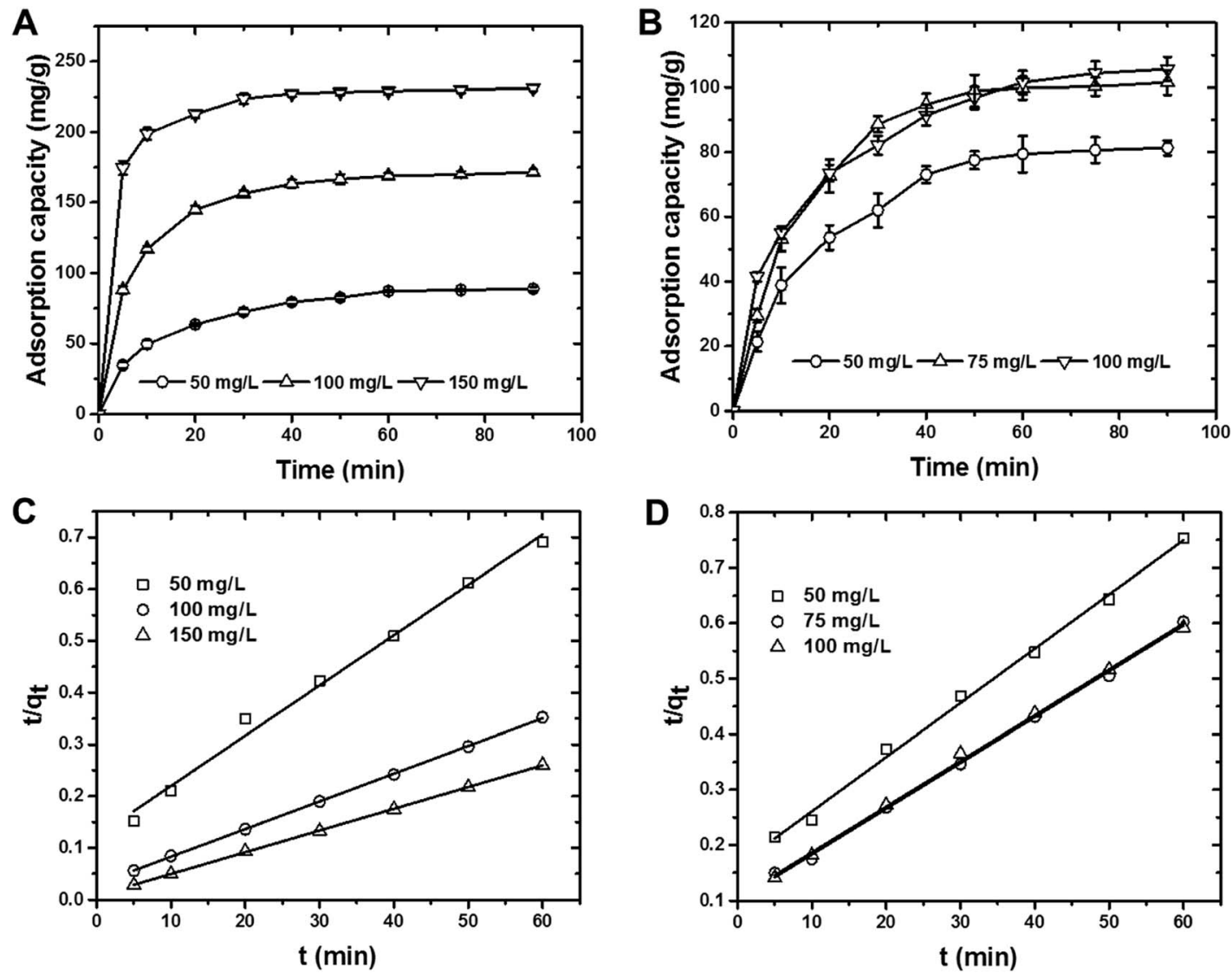

Fig. 2 Effects of contact time and initial concentrations on the removal of (A) $\mathrm{MO}$ dye and (B) $\mathrm{Cr}(\mathrm{vI})$ ions by the $\mathrm{CS}(\mathrm{pH}=7.0, \mathrm{MO}$ dye and $\mathrm{Cr}(\mathrm{VI})$ ion concentrations varied from $50-150 \mathrm{mg} \mathrm{L}^{-1}$ and $50-100 \mathrm{mg} \mathrm{L}^{-1}$, respectively, volume $=10 \mathrm{~mL}$, dosage $=5 \mathrm{mg}$, and temperature $=295 \mathrm{~K}$ ), and pseudo-second-order kinetic graph obtained for (C) $\mathrm{MO}$ dye and (D) $\mathrm{Cr}(\mathrm{VI})$ ions removal by the $\mathrm{CS}(\mathrm{pH}=7.0, \mathrm{MO}$ dye and $\mathrm{Cr}(\mathrm{VI})$ ion concentrations varied from $50-150 \mathrm{mg} \mathrm{L}^{-1}$ and $50-100 \mathrm{mg} \mathrm{L}^{-1}$, respectively, volume $=10 \mathrm{~mL}$, dosage $=5 \mathrm{mg}$, and temperature $=295 \mathrm{~K}$ ) 
Table 1 Kinetic parameters obtained for MO dye and $\mathrm{Cr}(\mathrm{VI})$ ion removal using CS

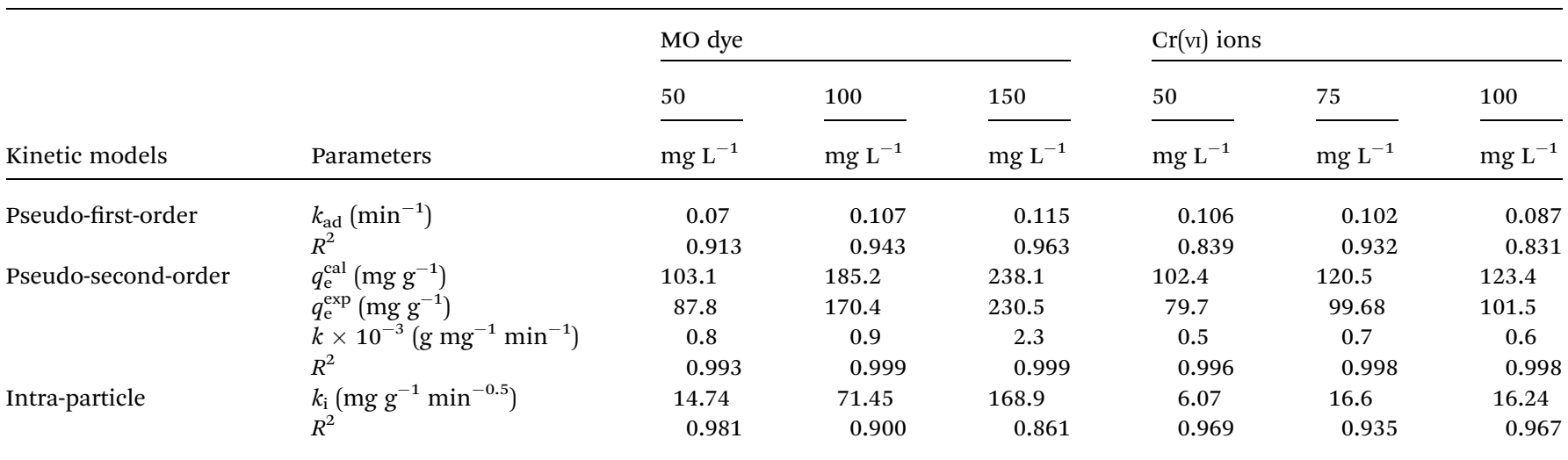

kinetic models. The kinetic parameters were calculated by plotting the respective linear graph of eqn (S1-S3) $\dagger$ (Table 1). The pseudo-second-order kinetic model exhibited the best fit with correlation coefficient $\left(R^{2}\right)$ values $>0.99$ for $\mathrm{Cr}(\mathrm{vI})$ ions and MO dye for all cases with CS (Fig. 2C and D).

Effect of $\mathbf{p H}$. An important parameter that can significantly affect the adsorption process, $\mathrm{pH}$ is shown in Fig. 3A for $\mathrm{Cr}(\mathrm{vI})$ ions and MO dye by the CS. The removal of $\mathrm{Cr}(\mathrm{vI})$ ions and $\mathrm{MO}$ dye by CS decreased with the increase in solution pH (Fig. 3A). The adsorption capacity for MO dye and $\mathrm{Cr}(\mathrm{vI})$ ions changed from 95.6 and $92.9 \mathrm{mg} \mathrm{g}^{-1}$ to 78.4 and $50.4 \mathrm{mg} \mathrm{g}^{-1}$, respectively, with the increase in $\mathrm{pH}$ from 3 to 9. In addition, the $\mathrm{pH}_{\mathrm{ZPC}}$ of the CS was determined as 5.06 using the salt addition method (Fig. S1†). The CS surface charge, which became more negative
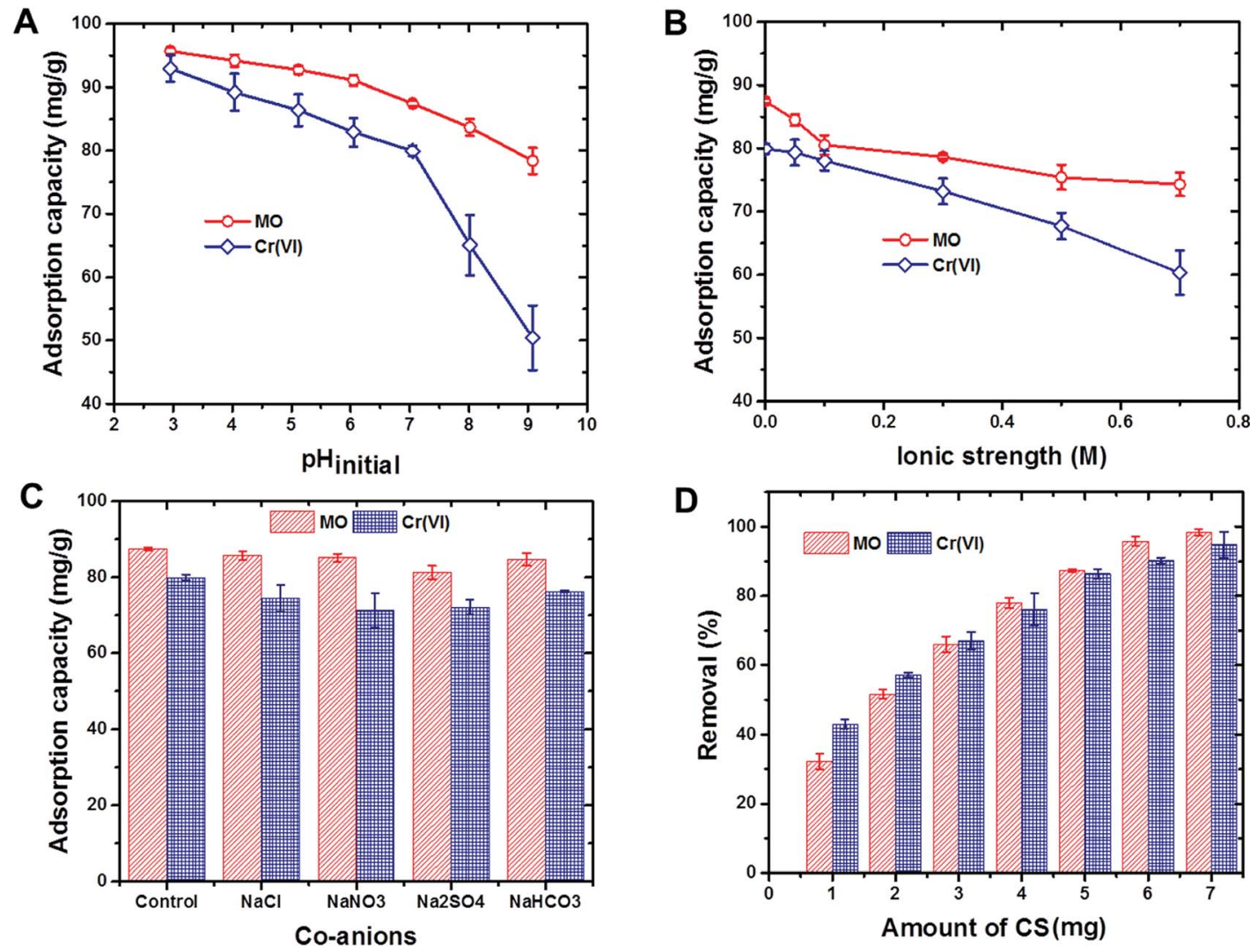

Fig. 3 (A) Influence of solution $\mathrm{pH}$ on the removal of $\mathrm{MO}$ dye and $\mathrm{Cr}(\mathrm{VI})$ ions by the $\mathrm{CS}$ ( $\mathrm{MO}$ dye and $\mathrm{Cr}(\mathrm{VI})$ ion concentrations $=50 \mathrm{mg} \mathrm{L}^{-1}$, contact time $=60 \mathrm{~min}$, volume $=10 \mathrm{~mL}$, dosage $=5 \mathrm{mg}$ and temperature $=295 \mathrm{~K}$ ). (B) Influence of solution ionic strength on the removal of $\mathrm{MO}$ dye and $\mathrm{Cr}(\mathrm{VI})$ ions by the $\mathrm{CS}$ ( $\mathrm{MO}$ dye and $\mathrm{Cr}(\mathrm{VI})$ ion concentrations $=50 \mathrm{mg} \mathrm{L}^{-1}$, contact time $=60 \mathrm{~min}$, volume $=10 \mathrm{~mL}$, dosage $=5 \mathrm{mg}, \mathrm{NaCl}$ concentration $=0$ to $0.7 \mathrm{M}$ and temperature $=295 \mathrm{~K}$ ). (C) Influence of co-existing ions on the removal of $\mathrm{MO}$ dye and $\mathrm{Cr}(\mathrm{vI})$ ions by the $\mathrm{CS}(\mathrm{pH}=$ 7.0, $\mathrm{MO}$ dye and $\mathrm{Cr}(\mathrm{vI})$ ion concentrations $=50 \mathrm{mg} \mathrm{L}^{-1}$, contact time $=60 \mathrm{~min}$, volume $=10 \mathrm{~mL}$, dosage $=5 \mathrm{mg}$ and temperature $=295 \mathrm{~K}$ ). (D) Effect of CS dosage on the removal of $\mathrm{MO}$ dye and $\mathrm{Cr}(\mathrm{VI})$ ions $\left(\mathrm{pH}=7.0, \mathrm{MO}\right.$ dye and $\mathrm{Cr}(\mathrm{VI})$ ion concentrations $=50 \mathrm{mg} \mathrm{L}^{-1}$, contact time $=$ $60 \mathrm{~min}$, volume $=10 \mathrm{~mL}$, dosage $=1$ to $7 \mathrm{mg}$ and temperature $=295 \mathrm{~K}$ ). 
at $\mathrm{pH}$ values higher than 5.06 , thus led to stronger electrostatic repulsions between the CS surface and the $\mathrm{Cr}(\mathrm{vI})$ ions $\left(\mathrm{HCrO}_{4}{ }^{-}\right)$ or the anionic MO dye. This finding might be the result of the decreased adsorption capacity of CS in addition to its competition with the $\mathrm{OH}^{-}$ions for the same adsorption sites. Similarly, at $\mathrm{pH}$ values lower than 5.06, the CS surface charge became more positive and led to stronger electrostatic interactions between the CS surface and the $\mathrm{Cr}(\mathrm{vI})$ ions/MO dye. After adsorption, $\mathrm{pH}$ of the treated solution was measured and found to be in the range of 5.0-6.0.

Effects of co-ion and ionic strength. Because the variable ionic strength of industrial effluents may interfere with the adsorption, the effects of co-ions and of ionic strength were also evaluated in the presence of several ions. The adsorption capacities of CS for $\mathrm{Cr}(\mathrm{VI})$ ions and for MO dye decreased with the increase in ionic strength (Fig. 3B). The weakening in the electrostatic attraction between the adsorbate and adsorbent may occur due to the decrease in surface and zeta potentials as the ionic strength increased, which typically reduce the adsorption capacity of the CS. ${ }^{\mathbf{4 4 5}}$ The adsorption capacities of the $\mathrm{CS}$ for $\mathrm{Cr}(\mathrm{vI})$ ions and for $\mathrm{MO}$ were examined in the presence of competing anions, i.e., $\mathrm{NO}_{3}{ }^{-}, \mathrm{SO}_{4}{ }^{2-}, \mathrm{HCO}_{3}{ }^{-}$and $\mathrm{Cl}^{-}$ions, and no significant inhibition was observed in terms of adsorption capacity (Fig. 3C). This confirms that the CS maintains its selectivity toward MO dye and $\mathrm{Cr}(\mathrm{vI})$ ions even in the presence of competing anions. Fig. 3D shows the influence of CS dosage on the removal of $\mathrm{Cr}(\mathrm{vI})$ ions and MO dye. Increasing the CS dosage from 1 to $7 \mathrm{mg}$, for example, improved the removal efficiencies from $43.0 \%$ and $32.3 \%$ to $94.7 \%$ and $98.3 \%$ for $\mathrm{Cr}(\mathrm{vI})$ ions and MO dye, respectively. This finding of greater adsorption at the higher CS dosage is the result of the increased number of sorption sites that can adsorb the $\mathrm{Cr}(\mathrm{vI})$ ions and $\mathrm{MO}$ dye.

Adsorption isotherm. The parameters for the Langmuir, Freundlich and D-R isotherm models were determined using eqn (S4-S6†) $\dagger$ (Table 2). The adsorption capacities form all three isotherms $\left(Q^{0}, q^{\max }\right.$ and $\left.X_{\mathrm{m}}\right)$ were increased with the temperature confirmed the endothermic nature of the adsorption processes. The $R_{\mathrm{L}}$ and $1 / n$ values calculated less than one, confirmed the favorable conditions for the adsorption of $\mathrm{Cr}(\mathrm{vI})$ ions and MO dye to the CS. The Freundlich model exhibited the best fit (higher $R^{2}$ value) for $\mathrm{Cr}(\mathrm{vI})$ ion removal by the CS. For MO dye, the Langmuir isotherm model was the best fit (higher $R^{2}$ value). The Langmuir maximum sorption capacity of the CS for MO dye was calculated as $385 \mathrm{mg} \mathrm{g}^{-1}$, while for $\mathrm{Cr}(\mathrm{vI})$ ions it was $139 \mathrm{mg} \mathrm{g}^{-1}$ at $318 \mathrm{~K}$. A comparison of the maximum adsorption capacities of the CS for MO dye and $\mathrm{Cr}(\mathrm{vI})$ ions (Tables 3 and 4 ) with those of other biopolymer based adsorbents found that for $\mathrm{Cr}(\mathrm{vI})$ ions, the CS has superior adsorption capacity than most of the other adsorbents in the list.

The thermodynamic parameters were calculated by using eqn (S7 and S8 $\dagger) \dagger$ (Table 5). The feasibility and spontaneous nature of the adsorption process was reflected in the negative $\Delta G^{\mathrm{o}}$ values, which became less negative as the temperature increased. In addition, the positive $\Delta H^{\mathrm{o}}$ values indicated that the adsorption processes were endothermic, and the positive $\Delta S^{\mathrm{o}}$ values indicated increased randomness at the solid-liquid interface during the $\mathrm{Cr}(\mathrm{VI})$ ion and MO dye adsorption by CS.

Based on the removal efficiencies of the CS for both MO dye and $\mathrm{Cr}(\mathrm{vI})$ ions, CS capacity for regeneration and reuse did not significantly change, even after three successive cycles of reuse (Fig. S2 $\dagger$ ). This finding strongly supported the potential of using CS as a cost effective adsorbent for water purification applications.

\subsection{Mechanism of $\mathrm{Cr}(\mathrm{vI})$ ion and MO dye removal by the CS}

ATR-FTIR spectra of Cr(vI) ions and MO dye adsorbed on the CS were recorded and compared with that of the CS alone (Fig. 4A). Compared to the spectrum of CS by itself, that of CS with adsorbed MO dye showed new peaks at 824, 1113, 1366 and $1600 \mathrm{~cm}^{-1}$, which are assigned to $\mathrm{C}-\mathrm{H}$ (bending), $\mathrm{S}=\mathrm{O}, \mathrm{C}-\mathrm{N}$ and $\mathrm{C}=\mathrm{C}$ stretching vibrations, respectively. ${ }^{59}$ The FTIR spectra of $\mathrm{CS}$ with adsorbed $\mathrm{Cr}(\mathrm{vI})$ ions show slight shifts in the $-\mathrm{NH}_{2}$ and $-\mathrm{C}-\mathrm{N}$ peaks at $1552 \mathrm{~cm}^{-1}$ to $1544 \mathrm{~cm}^{-1}$ and $1398 \mathrm{~cm}^{-1}$ to $1375 \mathrm{~cm}^{-1}$, respectively. XPS analysis of CS with adsorbed $\mathrm{Cr}(\mathrm{vI})$ ions showed two new peaks at 587.3 and $577.9 \mathrm{eV}$ that corresponded to $\mathrm{Cr}$ (III) for $2 \mathrm{p} 1 / 2$ and $2 \mathrm{p} 3 / 2$, respectively (Fig. $4 \mathrm{~B}$ and $\mathrm{C})$, and this feature evidenced the reduction of highly toxic $\mathrm{Cr}(\mathrm{vI})$ in to the less toxic $\mathrm{Cr}(\mathrm{III})$ by $\mathrm{CS}^{60}$ Others have also observed the reduction of $\mathrm{Cr}(\mathrm{VI})$ with other adsorbent

Table 2 Isotherm parameters obtained for $\mathrm{MO}$ dye and $\mathrm{Cr}(\mathrm{VI})$ ion removal using $\mathrm{CS}$

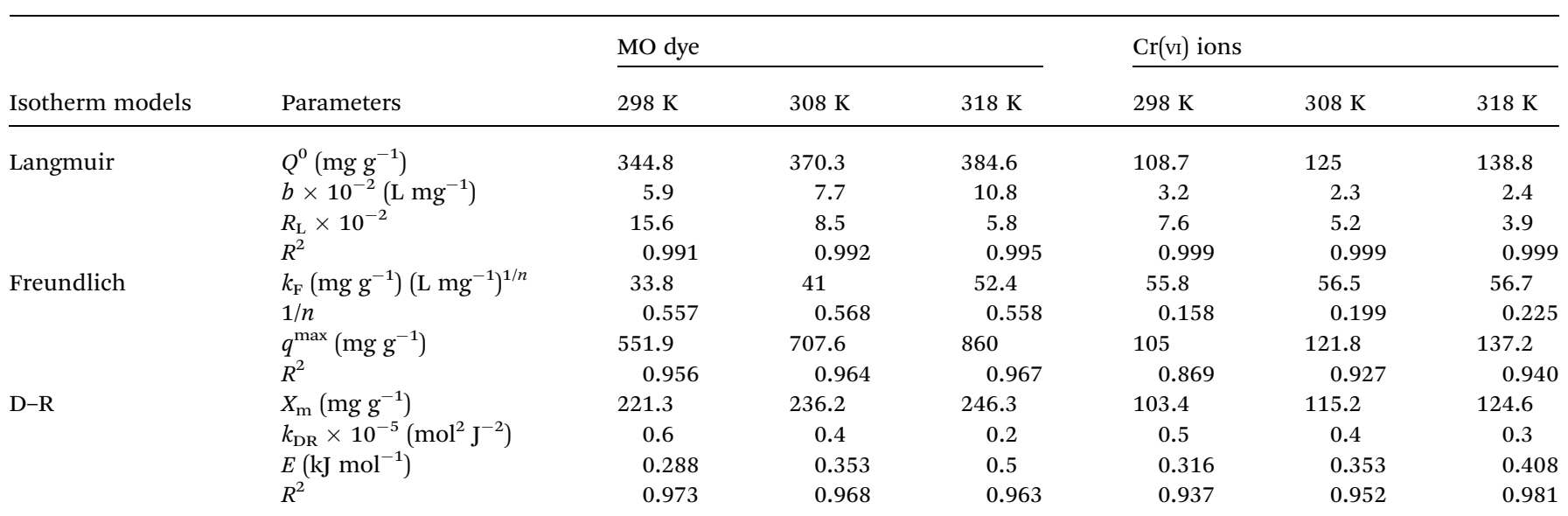


Table 3 Comparison of the maximum adsorption capacity of the CS for $\mathrm{Cr}(\mathrm{vI})$ ions with the adsorption capacities of other biopolymer based adsorbents

Polyaniline-chitosan composite

$\begin{array}{rr}165.6 & 20 \\ 28.6 & 46 \\ 78.6 & 47 \\ 35.2 & 48 \\ 73.3 & 5 \\ 28.7 & 49 \\ 26.5 & 49 \\ 17.8 & 50 \\ 21.5 & 50 \\ 23.1 & 50 \\ 19.4 & 51 \\ 24.5 & 51 \\ 25.4 & 51 \\ 19.1 & 52 \\ 9.2 & 24 \\ 33.3 & 53 \\ 175 & 23\end{array}$

Polyaniline-chitin composite

Polypyrrole-chitosan composite

Polypyrrole-chitin composite

Polyaniline-sodium alginate composite

Iron oxide coated cellulose/hydrotalcite composite

Iron oxide coated cellulose/hydroxyapatite composite

This study

Cerium loaded alginate-bentonite composite

Zirconium loaded alginate-bentonite composite

Calcium loaded alginate-gelatin composite

Cerium loaded alginate-gelatin composite

Zirconium loaded alginate-gelatin composite

Hydroxyapatite-gelatin composite

Lanthanum loaded chitosan-silica gel composite

Chitosan coated fly ash composite

138.8

Table 4 Comparison of maximum adsorption capacity of the CS for MO dye with the adsorption capacities of other biopolymer based adsorbents

\begin{tabular}{|c|c|c|}
\hline Adsorbent materials & $\begin{array}{l}\text { Maximum adsorption } \\
\text { capacity }\left(\mathrm{mg} \mathrm{g}^{-1}\right)\end{array}$ & Reference \\
\hline Chitosan-magnetic composite & 758 & 54 \\
\hline Chitosan $/ \mathrm{Al}_{2} \mathrm{O}_{3} /$ magnetite nanoparticles composite & 417 & 55 \\
\hline Chitosan doped with graphene oxide & 686.9 & 56 \\
\hline Magnetic chitosan-graphene oxide composite & 398 & 28 \\
\hline Graphene oxide/chitosan aerogel & 189.4 & 57 \\
\hline Chitosan/organic rectorite magnetic composite & 5.56 & 58 \\
\hline Chitosan-sericin composite & 384.6 & This study \\
\hline
\end{tabular}

compositions $^{61-63}$ and possible mechanisms have been described in detail including the direct reduction of the $\mathrm{Cr}(\mathrm{vI})$ in solution or $\mathrm{Cr}(\mathrm{vI})$ adsorption and concomitant reduction. ${ }^{64}$ The CS conjugate presently reported contains many electron rich groups such as hydroxyl and amine groups that might take part in the reduction process. The reduction of $\mathrm{Cr}(\mathrm{VI})$ to $\mathrm{Cr}(\mathrm{III})$ is a great advantage with this new CS adsorbent, and this $\operatorname{Cr}(\mathrm{vI})$ adsorption on CS was further supported by EDX measurements (Fig. S3†). ATR-FTIR and XPS analyses supported that electrostatic attraction played a role in the MO dye removal mechanism by the CS, together with hydrophobic and other interactions. Whereas, the removal of $\mathrm{Cr}(\mathrm{vI})$ ions by the CS was driven mainly by electrostatic adsorption coupled with the beneficial feature of reduction. Fig. $\mathrm{S} 5 \dagger$ is a schematic illustration depicting these possible mechanisms of $\mathrm{Cr}(\mathrm{vI})$ ion and $\mathrm{MO}$ dye adsorption on the CS.

\subsection{Co-adsorption of $\mathrm{Cr}(\mathrm{vI})$ ions and MO dye by the CS from the binary mixture}

The potential of the CS to remove $\mathrm{Cr}(\mathrm{vI})$ ions and MO dye from the binary mixture by co-adsorption was evaluated at different solution $\mathrm{pH}$ values (Fig. $\mathrm{S} 4 \dagger$ ). $\mathrm{Cr}(\mathrm{vI})$ ion and $\mathrm{MO}$ dye removal rates by the $\mathrm{CS}$ decreased with increases in solution $\mathrm{pH}$, which

Table 5 Thermodynamic parameters calculated for $\mathrm{MO}$ dye and $\mathrm{Cr}(\mathrm{vI})$ ion removal by the CS

\begin{tabular}{lccc}
\hline Thermodynamic parameters & MO dye & Cr(vi) ions \\
\hline$\Delta G^{\mathrm{o}}(\mathrm{kJ} \mathrm{mol}$ & \\
& $298 \mathrm{~K}$ & -9.1 & -8.56 \\
& $308 \mathrm{~K}$ & -8.7 & -8.55 \\
$\Delta H^{\mathrm{o}}\left(\mathrm{kJ} \mathrm{mol}^{-1}\right)$ & $318 \mathrm{~K}$ & -8.09 & -8.55 \\
$\Delta S^{\mathrm{o}}\left(\mathrm{kJ} \mathrm{mol}^{-1} \mathrm{~K}^{-1}\right)$ & & 23.6 & 8.44 \\
& & 0.05 & 0.001
\end{tabular}



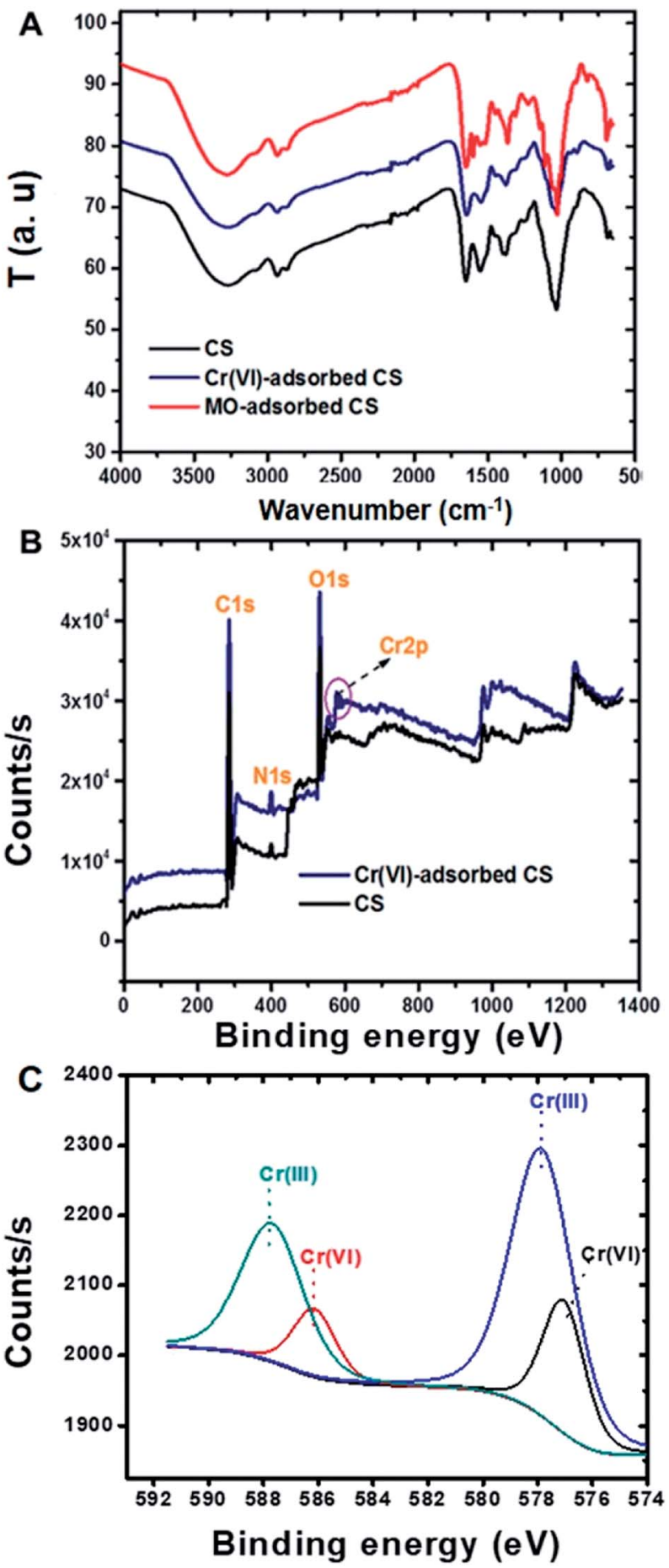

Fig. 4 (A) ATR-FTIR spectra of the CS alone and of CS with adsorbed $\mathrm{Cr}(\mathrm{VI})$ ions and $\mathrm{MO}$ dye. (B) XPS general survey of the CS alone and with adsorbed $\mathrm{Cr}(\mathrm{VI})$ ions. (C) XPS spectra (de-convoluted) of CS with adsorbed $\mathrm{Cr}(\mathrm{VI})$ ions.

reflects the findings of the $\mathrm{pH}$ study (see Section 3.1). However, in the presence of MO dye, the CS selectivity toward $\mathrm{Cr}(\mathrm{vI})$ ions was significantly influenced, while the selectivity of MO dye was not altered throughout the $\mathrm{pH}$ ranges studied. The competition between the $\mathrm{Cr}(\mathrm{vI})$ ions and MO dye for the same adsorption sites might have caused the observed reduction in $\mathrm{Cr}(\mathrm{VI})$ ion removal rates. These findings clearly indicate that the CS can be used for the removal of both $\mathrm{Cr}(\mathrm{vI})$ ions and MO dye from such mixtures, though the removal efficiency will be greater for the dye.

\section{Conclusions}

Sericin, a waste product of silk production, was successfully converted into a useful, environmentally friendly adsorbent with chitosan and then used for the removal of $\mathrm{Cr}(\mathrm{vI})$ ions and MO dye from aqueous solutions. $\mathrm{P}_{\mathrm{ZPC}}$ and $\mathrm{pH}$ studies confirmed that the CS is positively charged and results in a higher adsorption capacity with decreased $\mathrm{pH}$ for $\mathrm{MO}$ dye and $\mathrm{Cr}(\mathrm{vI})$ ions. The presence of co-ions have not shown any effect on either MO dye or $\mathrm{Cr}(\mathrm{vI})$ ion removal, whereas increases in ionic strength led to decreases in adsorption capacities that were probably due to decreased surface and zeta potentials of the adsorbent. $\mathrm{Cr}(\mathrm{vI})$ ion and MO dye removal followed pseudosecond-order kinetics and the Langmuir isotherm model. The maximum CS monolayer adsorption capacities for $\mathrm{Cr}(\mathrm{vI})$ and MO dye ions were calculated as 385 and $139 \mathrm{mg} \mathrm{g}^{-1}$, respectively. These calculated values are significantly higher than those of most chitosan-based adsorbents. Electrostatic attraction was played a role in MO dye removal along with hydrophobic and other effects, whereas electrostatic adsorption coupled with reduction was the main mechanisms behind $\mathrm{Cr}(\mathrm{vI})$ ion removal. Furthermore, its reusability and its ability to simultaneously remove multiple ions make CS an excellent adsorbent for the efficient treatment of industrial effluents.

\section{Conflicts of interest}

There are no conflicts of interest to declare.

\section{Acknowledgements}

The author (K. R.) thanks the Blaustein Center for Scientific Cooperation (Ben-Gurion University of the Negev) for a postdoctorate fellowship. We are grateful to the United StatesIsrael Binational Science Foundation (BSF Grant No. 2014233) for financial support. C. J. A. wishes to thank the Canadian Associates of Ben Gurion University (CABGU) Quebec region for support.

\section{References}

1 G. Z. Kyzas, P. I. Siafaka, D. A. Lambropoulou, N. K. Lazaridis and D. N. Bikiaris, Langmuir, 2014, 30, 120-131.

2 R. Mallampati, L. Xuanjun, A. Adin and S. Valiyaveettil, ACS Sustainable Chem. Eng., 2015, 3, 1117-1124.

3 B. Qiu, C. Xu, D. Sun, H. Wei, X. Zhang, J. Guo, Q. Wang, D. Rutman, Z. Guo and S. Wei, RSC Adv., 2014, 4, 2985529865.

4 R. Karthik and S. Meenakshi, Chem. Eng. J., 2015, 263, 168177. 
5 R. Karthik and S. Meenakshi, Int. J. Biol. Macromol., 2015, 78, 157-164.

6 K. Rathinam, S. P. Singh, Y. Li, R. Kasher, J. M. Tour and C. J. Arnusch, Carbon, 2017, 124, 515-524.

7 X. Wei, X. Kong, S. Wang, H. Xiang, J. Wang and J. Chen, Ind. Eng. Chem. Res., 2013, 52, 17583-17590.

8 M. Li, Z. Lv, J. Zheng, J. Hu, C. Jiang, M. Ueda, X. Zhang and L. Wang, ACS Sustainable Chem. Eng., 2017, 5, 784-792.

9 S. Sansuk, S. Srijaranai and S. Srijaranai, Environ. Sci. Technol., 2016, 50, 6477-6484.

10 S. Luo, F. Qin, Y. a. Ming, H. Zhao, Y. Liu and R. Chen, J. Hazard. Mater., 2017, 340, 253-262.

11 X. Ruan, Y. Xu, X. Liao, G. He, X. Yan, Y. Dai, N. Zhang and L. Du, AIChE J., 2017, 63, 4541-4548.

12 L. Zhou, J. Lei, L. Wang, Y. Liu and J. Zhang, Appl. Catal., B, 2017, DOI: 10.1016/j.apcatb.2017.08.039.

13 X. Cui, T. Li, S. Yao, L. An, Y. Li, Z. Zhou, M. Guo and Z. Zhang, RSC Adv., 2016, 6, 96237-96244.

14 I. Ali, Chem. Rev., 2012, 112, 5073-5091.

15 M. Arshadi, F. SalimiVahid, J. W. L. Salvacion and M. Soleymanzadeh, RSC Adv., 2014, 4, 16005-16017.

16 M. Vakili, M. Rafatullah, B. Salamatinia, A. Z. Abdullah, M. H. Ibrahim, K. B. Tan, Z. Gholami and P. Amouzgar, Carbohydr. Polym., 2014, 113, 115-130.

17 W. S. Wan Ngah, L. C. Teong and M. A. K. M. Hanafiah, Carbohydr. Polym., 2011, 83, 1446-1456.

18 G. Crini, Prog. Polym. Sci., 2005, 30, 38-70.

19 M. Monier and D. A. Abdel-Latif, J. Hazard. Mater., 2012, 209, 240-249.

20 R. Karthik and S. Meenakshi, Int. J. Biol. Macromol., 2014, 67, 210-219.

21 X. Huang, Y. Liu, S. Liu, X. Tan, Y. Ding, G. Zeng, Y. Zhou, M. Zhang, S. Wang and B. Zheng, RSC Adv., 2016, 6, 94-104.

22 Y. Chen, L. Chen, H. Bai and L. Li, J. Mater. Chem. A, 2013, 1, 1992-2001.

23 L. Zhang, W. Xia, B. Teng, X. Liu and W. Zhang, Chem. Eng. J., 2013, 229, 1-8.

24 M. R. Gandhi and S. Meenakshi, J. Hazard. Mater., 2012, 203, 29-37.

25 L. Zhang, P. Hu, J. Wang, Q. Liu and R. Huang, Int. J. Biol. Macromol., 2015, 81, 818-827.

26 R. Huang, Q. Liu, L. Zhang and B. Yang, Water Sci. Technol., 2015, 71, 174-182.

27 R. Jiang, Y.-Q. Fu, H.-Y. Zhu, J. Yao and L. Xiao, J. Appl. Polym. Sci., 2012, 125, E540-E549.

28 Y. Jiang, J.-L. Gong, G.-M. Zeng, X.-M. Ou, Y.-N. Chang, C.-H. Deng, J. Zhang, H.-Y. Liu and S.-Y. Huang, Int. J. Biol. Macromol., 2016, 82, 702-710.

29 G. Crini, Bioresour. Technol., 2006, 97, 1061-1085.

30 Y.-Q. Zhang, Biotechnol. Adv., 2002, 20, 91-100.

31 T.-T. Cao and Y.-Q. Zhang, Mater. Sci. Eng., C, 2016, 61, 940952.

32 B. Kundu and S. C. Kundu, Biomaterials, 2012, 33, 74567467.

33 Z. Wang, Y. Zhang, J. Zhang, L. Huang, J. Liu, Y. Li, G. Zhang, S. C. Kundu and L. Wang, Sci. Rep., 2014, 4, 7064.
34 J. Karpus, M. Bosscher, I. Ajiboye, L. Zhang and C. He, ChemBioChem, 2017, 18, 633-637.

35 H. W. Kwak and K. H. Lee, Chemosphere, 2018, 207, 507-516.

36 T. Mahmood, M. T. Saddique, A. Naeem, P. Westerhoff,

S. Mustafa and A. Alum, Ind. Eng. Chem. Res., 2011, 50, 10017-10023.

37 Y. Yang, Y. Chun, G. Sheng and M. Huang, Langmuir, 2004, 20, 6736-6741.

38 R. Karthik and S. Meenakshi, Journal of Water Process Engineering, 2014, 1, 37-45.

39 I. Migneault, C. Dartiguenave, M. J. Bertrand and K. C. Waldron, BioTechniques, 2004, 37, 790-802.

40 D. T. Cheung and M. E. Nimni, Connect. Tissue Res., 1982, 10, 187-199.

41 O. Barbosa, C. Ortiz, Á. Berenguer-Murcia, R. Torres, R. C. Rodrigues and R. Fernandez-Lafuente, RSC Adv., 2014, 4, 1583-1600.

42 R. Zhao, X. Li, B. Sun, Y. Zhang, D. Zhang, Z. Tang, X. Chen and C. Wang, Int. J. Biol. Macromol., 2014, 68, 92-97.

43 M. Sunilkumar, T. Francis, E. T. Thachil and A. Sujith, Chem. Eng. J., 2012, 204, 114-124.

44 A. C. Zimmermann, A. Mecabô, T. Fagundes and C. A. Rodrigues, J. Hazard. Mater., 2010, 179, 192-196.

45 M. A. Brown, A. Goel and Z. Abbas, Angew. Chem., Int. Ed., 2016, 55, 3790-3794.

46 R. Karthik and S. Meenakshi, Int. J. Biol. Macromol., 2015, 72, 235-242.

47 R. Karthik and S. Meenakshi, Desalin. Water Treat., 2015, 56, 1587-1600.

48 R. Karthik and S. Meenakshi, Synth. Met., 2014, 198, 181187.

49 S. Periyasamy, V. Gopalakannan and N. Viswanathan, Carbohydr. Polym., 2017, 174, 352-359.

50 V. Gopalakannan, S. Periyasamy and N. Viswanathan, Carbohydr. Polym., 2016, 151, 1100-1109.

51 V. Gopalakannan and N. Viswanathan, Int. J. Biol. Macromol., 2016, 83, 450-459.

52 V. Gopalakannan and N. Viswanathan, Ind. Eng. Chem. Res., 2015, 54, 12561-12569.

53 Y. Wen, Z. Tang, Y. Chen and Y. Gu, Chem. Eng. J., 2011, 175, 110-116.

54 D. Yang, L. Qiu and Y. Yang, J. Chem. Eng. Data, 2016, 61, 3933-3940.

55 B. Tanhaei, A. Ayati, M. Lahtinen and M. Sillanpää, Chem. Eng. J., 2015, 259, 1-10.

56 Y. Wang, G. Xia, C. Wu, J. Sun, R. Song and W. Huang, Carbohydr. Polym., 2015, 115, 686-693.

57 R. Yu, Y. Shi, D. Yang, Y. Liu, J. Qu and Z.-Z. Yu, ACS Appl. Mater. Interfaces, 2017, 9, 21809-21819.

58 L. Zeng, M. Xie, Q. Zhang, Y. Kang, X. Guo, H. Xiao, Y. Peng and J. Luo, Carbohydr. Polym., 2015, 123, 89-98.

59 Y. Liu, C. Luo, J. Sun, H. Li, Z. Sun and S. Yan, J. Mater. Chem. $A, 2015,3,5674-5682$.

60 T. Zhou, C. Li, H. Jin, Y. Lian and W. Han, ACS Appl. Mater. Interfaces, 2017, 9, 6030-6043.

61 W. Liu, L. Yang, S. Xu, Y. Chen, B. Liu, Z. Li and C. Jiang, RSC Adv., 2018, 8, 15087-15093. 
62 D.-M. Guo, Q.-D. An, Z.-Y. Xiao, S.-R. Zhai and Z. Shi, RSC Adv., 2017, 7, 54039-54052.

63 K. Rathinam, S. P. Singh, C. J. Arnusch and R. Kasher, Carbohydr. Polym., 2018, 199, 506-515.
64 D. Park, Y.-S. Yun, H. W. Lee and J. M. Park, Bioresour. Technol., 2008, 99, 1141-1147. 